\title{
Correction to: Introduction to a Special Section on the Effects of the Dating Matters Model on Secondary Outcomes: Results from a Comparative Effectiveness Cluster Randomized Controlled Trial
}

\section{Phyllis Holditch Niolon ${ }^{1}$}

Published online: 18 January 2021

(C) Society for Prevention Research 2021

\section{Correction to: Prevention Science}

https://doi.org/10.1007/s11121-020-01187-3

The original version of this article unfortunately contained a typographical error in the text body. All occurrences of the citation "Debman and Temple (in press)" should be presented as "Debnam and Temple (2020)". The bibliographic details of this reference should also be updated from "in press" to:

Debnam, K.J., \& Temple, J. R. (2020). Dating matters and the future of teen dating violence prevention. Prevention Science. https://doi.org/10.1007/s11121-020-01169-5.

The original article has been corrected.

Publisher's Note Springer Nature remains neutral with regard to jurisdictional claims in published maps and institutional affiliations.

The online version of the original article can be found at https://doi.org/ 10.1007/s11121-020-01187-3

Phyllis Holditch Niolon pniolon@cdc.gov

1 Division of Violence Prevention, Centers for Disease Control and Prevention, 4770 Buford Highway, MS 106-10, Atlanta, GA 30341, USA 